\title{
Redeposited chalk hydrocarbon reservoirs of the North Sea caused by the Chicxulub K-T bolide impact
}

\section{Rider ${ }^{1} \&$ D. Kroon ${ }^{2}$}

${ }^{1}$ School of GeoSciences, Grant Institute, University of Edinburgh, Edinburgh EH9 3JW, UK. malcolm.rider@glg.ed.ac.uk (corresponding author)

${ }^{2}$ Faculty of Earth and Life Sciences, Vrije Universiteit, De Boelelaan 1085, 1081 HV Amsterdam, The Netherlands. E-mail: kro@geo.vu.nl

Manuscript received: January 2003; accepted: June 2003

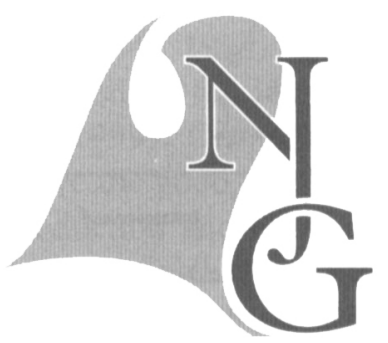

\begin{abstract}
A widespread, slumped, redeposited, uppermost Cretaceous chalk interval, up to $60 \mathrm{~m}$ thick, immediately below the Cretaceous-Tertiary (K-T) boundary, recognised in oil company boreholes across the central North Sea and a major hydrocarbon reservoir, we re-interpret as the result of a single, catastrophic event caused by secondary effects related to the bolide impact at Chicxulub. A thin, dark clay bed immediately above the redeposited chalks, we suggest correlates to the outcropping, Iridium rich, Danish 'Fish Clay', rapidly deposited after the impact. Physical effects on sea-floor sediments, caused by the K-T bolide impact, have not previously been interpreted in the North Sea.
\end{abstract}

Keywords: K-T boundary, bolide impact, redeposited chalk, slump

\section{Introduction}

The effects of the end Cretaceous bolide impact, at Chicxulub, Yucatan, Mexico, on the physical state of sea floor sediments in the Gulf of Mexico and the Northwestern Atlantic, far from the impact site, are only now being identified (eg. Bralower et al., 1998). Slump scars, recognised in Ocean Drilling Project Sites 1049, 1050 and 1052 in the Blake Nose area off eastern Florida, $1600 \mathrm{~km}$ away from the impact site, have been convincingly correlated to the CretaceousTertiary (K-T) boundary event (Klaus et al., 2000), although un-related slumps may also be present (MacLeod et al. 2003). More recently, it has been proposed that slope failure, caused by the shock waves of the impact, was even more widespread and extended all along the eastern US seaboard from Florida to Nova Scotia (Norris et al., 2000). If such a scale of failure did occur along the entire western North Atlantic margin, it would have created a signif- icant oceanic wave (tsunami) that could have had huge effects on the eastern, European side of the North Atlantic, which was closer to the western margin during the Cretaceous. Slope failure of the eastern North Atlantic margin has been recognised in DSDP Hole 398D on the Iberian Abyssal Plain (Norris \& Firth, 2002) and it is conceivable that at least parts of the eastern margin of the North Atlantic would have failed catastrophically. In this paper, we suggest that the North Sea was also affected by the consequences of the bolide impact at Chicxulub.

The North Sea chalk basin (Fig. 1), although not on the North Atlantic margin proper, has been extensively drilled by the oil industry and many boreholes provide continuous records of the uppermost Cretaceous and lowermost Danian, the interval of the K-T boundary. We re-interpret the extensive, mainly published hydrocarbon industry data, to indicate that the well documented slumping and redeposition of chalks (D’Heur, 1986; Kennedy, 1987; Bramwell et al., 


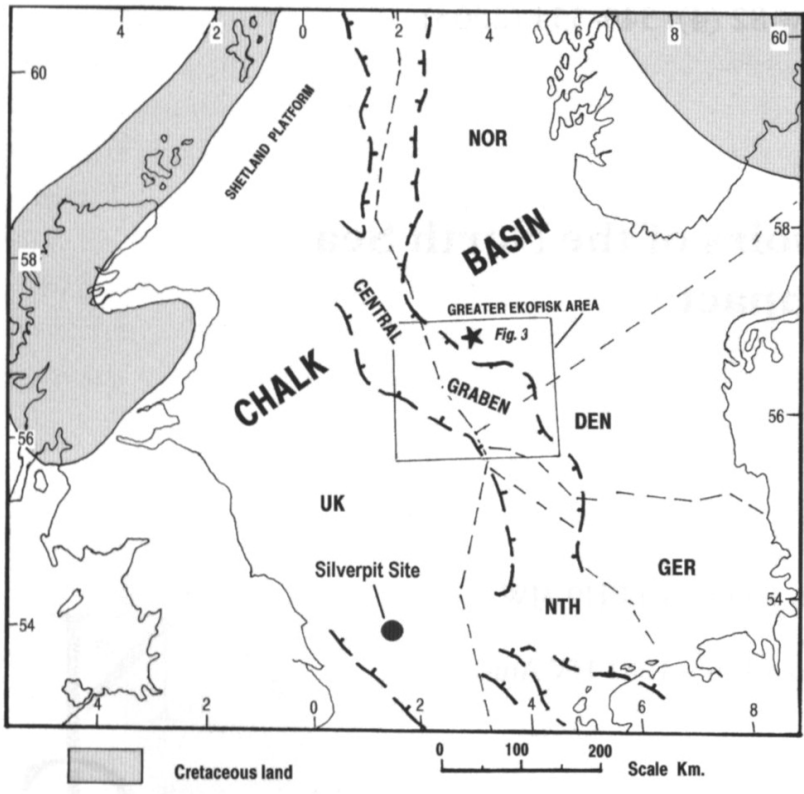

Figure 1. The North Sea Chalk basin and land areas at the time of the K-T boundary (Ziegler 1990). The Greater Ekofisk Area, indicated by the box, contains the principal chalk oil fields and is the main focus of this paper. The Silverpit Site is the site of the possible bolide impact (Stewart \& Allen, 2002). The national offshore exploration areas are indicated, UK, United Kingdom: NOR, Norway: DEN, Denmark: GER, Germany: NTH, Netherlands.

1999; Mackertich \& Goulding, 1999; Brasher \& Vagle, 1996) in the latest Maastrichtian, are indirectly related to disturbances at the Cretaceous-Tertiary (K-T) boundary and represent a single event.

\section{North Sea stratigraphy across the K-T bound- ary}

The sequence of sediments across the K-T boundary is familiar to the hydrocarbon industry working in the North Sea and since the sequence has been cored, the detailed lithology is known (D'Heur, 1986; Kennedy, 1987; Bramwell et al., 1999; Brasher \& Vagle, 1996; Johnson \& Lott, 1993). It consists of chalks all through the Tor Formation, of latest Cretaceous, Maastrichtian age, and into the following Ekofisk Formation of earliest Tertiary, Danian age, although there are distinct lithological differences between the two formations (Fig. 2). The uppermost Maastrichtian, Tor Formation consists of very pure, pelagic, coccolith chalk (D'Heur, 1986; Kennedy, 1987; Brasher \& Vagle, 1996). Geographically it extends over much of the central and southern North Sea but in the centre of the chalk depositional basin, especially in the area of the Greater Ekofisk oil fields (Fig 1), it has been widely re-mobilised and redeposited. These so called allochthonous chalks may have been redeposited in a number of ways; in slides, slumps, debris-flows and turbidites (Kennedy, 1987), or even from a sediment cloud remaining after any of the preceding. The Ekofisk Formation chalks, which overlie the redeposited Tor Formation chalks, are quite distinct and are mainly well-layered, argillaceous, undisturbed, inplace periodites (D'Heur, 1986; Kennedy, 1987; Mackertich \& Goulding, 1999), with only isolated allochthonous intervals.

Continuous, geophysical well log records (wireline logs) allow the chalk formations to be identified where there is no core and correlated across the basin (D'Heur, 1986; Kennedy, 1987; Johnson and Lott, 1993). The redeposited Tor Formation has a variable but often thick development in the Greater Ekofisk area near the centre of the depositional basin (Brasher \& Vagle, 1996). Outside the central area, when present, it is mainly in-place or only slightly slumped. The succeeding Ekofisk Formation can be followed over a very large part of the North Sea basin with a relatively constant character and thickness (Johnson \& Lott, 1993). The chalk of the formation shows a progressive decrease in clay content upwards as indicated by the similar decrease gamma ray log values (Bramwell et al., 1999; Johnson \& Lott, 1993) but with the highest amount of clay (and highest gamma ray value) at the base, in the so called 'Ekofisk tight zone' (D'Heur, 1986; Fig. 2). It represents an abrupt and marked change in sedimentation from the very pure Maastrichtian chalks immediately below. The base of the Ekofisk Formation is generally marked by a distinct clay layer that has been called a condensed sequence and considered to have been deposited very slowly under conditions of anoxic bottom waters (Kennedy, 1987). We infer it to be the equivalent of the 'Fish Clay' of the Danish Stevns Klint outcrop, as do previous authors (Mackertich \& Goulding, 1999, Fig. 23; Ziegler, 1990) and so marks the K-T boundary itself. It represents the period immediately after the Chicxulub bolide impact and most likely accumulated very rapidly (Mukhopadyay et al., 2001) rather than very slowly, and, although no analyses have yet been done, it should contain high amounts of Iridium as it does on land in Denmark (Alvarez et al., 1980)

\section{Mass wasting at the K-T boundary}

It is generally considered that the uppermost Maastrichtian - lowermost Danian sequence across the North Sea is incomplete and that there is an unconformity between the two formations (Johnson \& Lott, 1993; Hancock and Scholle, 1975; Farmer \& Barkved, 1999). Sea level curves are drawn with a rapid excursion of shallowing and then deepening during the late Maastrichtian (Bramwell et al., 1999). 
Depth of deposition before and after this excursion is considered to have been the same. Although the basin margin appears to show sea level shallowing in the late Maastrichtian, at least over onshore Denmark, the actual K-T boundary shows continuous sedimentation (Surlyk, 1997). Our interpretation of the offshore data (not the outcrops) is that it marks the passage of a tsunami that swept the uppermost sediment layers from the shallower parts of the basin and caused significant redeposition in the basin centre. Sedimentation across the basin was actually continuous but the sediment record at many locations is not, which is consistent with the observation that the Tor Formation redeposited chalks are partly sourced with debris from shallower, marginal areas (D'Heur, 1986; Kennedy, 1987). That is, there was no unconformity in the usual sense of a break in sedimentation and time gap, and there was no longer term sea level change, only dramatic variations that occurred in a matter of minutes or hours as the tsunami passed. Clearly, as the changes in depositional environment and physical character of the chalks are related to impact effects, they can have no significance in terms of sequence stratigraphy and long term sea level changes, as has been suggested (Kennedy, 1987). Also, the variable thickness distribution of the end Maastrichtian redeposited chalks is related to the basin topography that existed at the time and is not

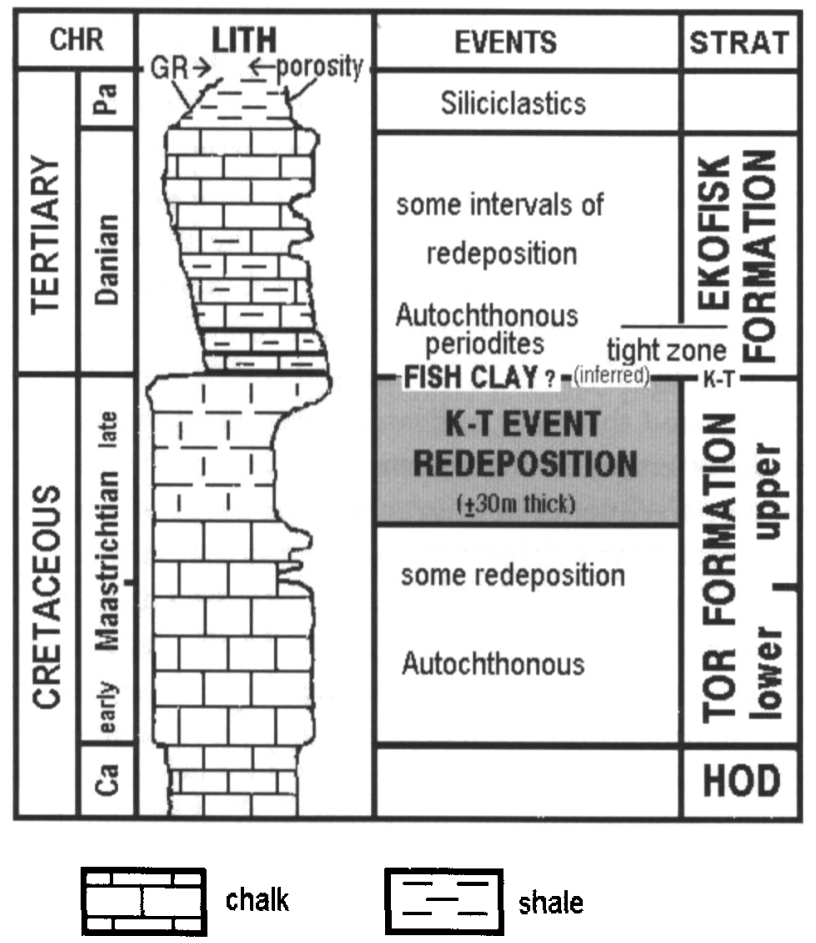

Figure 2. The North Sea stratigraphic section above and below the K-T boundary. The GR (gamma ray) and porosity curves are schematic. CHR, chronology: STRAT, litho-stratigraphy. $\mathrm{Ca}, \mathrm{Cam}-$ panian: Pa, Palaeocene. No vertical scale. controlled by fault activity as proposed (Farmer and Barkved, 1999). The sea floor following the slumping and redeposition would have become flat, with topographical variations at a minimum, which explains why the basal part of the succeeding Ekofisk Formation, consisting of laminated periodites (Kennedy, 1987) (the Ekofisk tight zone), is generally undisturbed and so widely distributed (Johnson and Lott, 1993).

To the oil industry, the redeposited chalks of the Tor Formation are of the utmost importance as they have very high porosity, good permeability, and provide the principal reservoir over the Greater Ekofisk area (D'Heur, 1986; Bramwell et al., 1999). They originally contained billions of barrels of oil, condensate and gas (Bramwell et al., 1999). Only chalks which have been redeposited have the good reservoir properties necessary for oil production and contrast strongly with the basal Ekofisk Formation (the tight zone) of autochthonous chalks, which have extremely low porosity and permeability and form a pressure barrier and seal over the re-sedimented chalk reservoir (D'Heur, 1986; Bramwell et al., 1999; Mackertich \& Goulding, 1999; Fig. 3). Although previous work created an understanding of this huge difference between allochthonous and autochthonous chalks, between reservoir and non-reservoir (Kennedy, 1987; Bramwell et al., 1999; Mackertich \& Goulding, 1999; Brasher \& Vagle, 1996), it was never clear why this difference had a stratigraphic context, as recognised (Mackertich \& Goulding, 1999), or why redeposition reached a climax at the end of the Maastrichtian (Bramwell et al., 1999). We suggest that this is because the principal interval of redeposited chalk at the top of the Tor Formation, at the termination of the Maastrichtian, was indirectly the result of the Chicxulub impact and hence, on such a wide scale (Bramwell et al., 1999), occurred only once.

Evidence that the redeposition and slumping at the top of the Tor Formation represents a single event is based, at this stage of on-going, borehole based research, on the correlation of the diagnostic interval across the central area (Fig. 3), its stratigraphic position and its unique physical (petrophysical) properties compared to the contiguous Ekofisk tight zone. For example, plots of porosity against permeability, show the allochthonous Tor chalks and the immediately overlying lower, autochthonous Ekofisk Formation, have completely different, internally coherent populations, with different depth related compaction trends (Bramwell et al., 1999; Mackertich \& Goulding, 1999). Fracture development also shows a unique, stratigraphically related development, the Tor Formation being fractured, the Ekofisk Formation not 


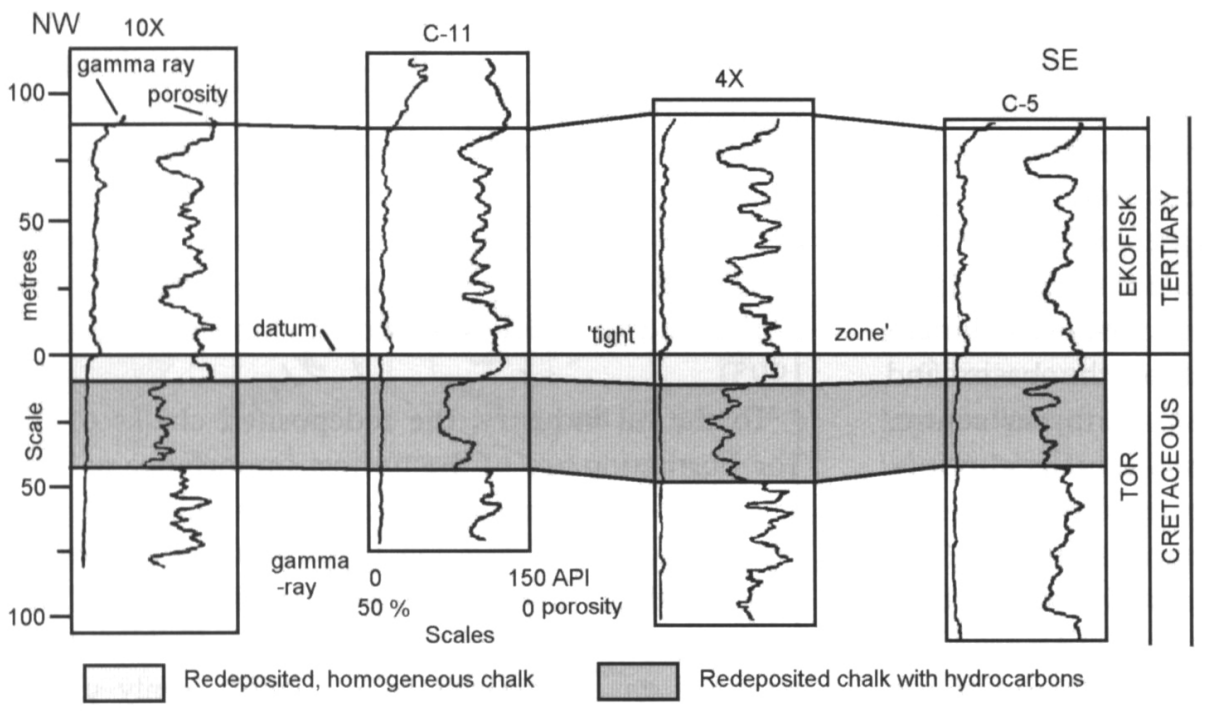

Figure 3. Example geophysical well log based correlation of the K-T, redeposited chalk interval (shaded). The porous, redeposited chalks contain hydrocarbons. Datum for the correlation is the base of the Ekofisk Formation, the K-T boundary. Section $3 \mathrm{~km}$ in length across the Edda Field (Norway, Block 2/7). See Figure 1 for location. After Brasher and Vagle (1996), re-drawn and modified.

(Mackertich \& Goulding, 1999). Although there are redeposited chalks in intervals other than in the topmost Tor Formation, they are not nearly as extensive and not uniquely followed in almost every location by a significant undisturbed interval, in this case the Ekofisk tight zone. This all suggests a unique, single event. In addition, dipmeter and electrical image logs can indicate slump geometry (Kennedy, 1987; Mackertich \& Goulding, 1999; Brasher \& Vagl, 1996). When that geometry is consistent, as indicated for example on the dipmeter in well 2/7-16 (Kennedy, 1987, Fig. 3), where a strong, NW-SE slump fold axis is consistent over $30 \mathrm{~m}$ of vertical section, it is unlikely to have been caused by separate episodes: this entire $30 \mathrm{~m}$ thick slump, stratigraphically immediately below the K-T boundary, represents just one, redeposition event. Seismic attribute, especially amplitude mapping over the Greater Ekofisk area (Bramwell et al., 1999; Brasher \& Vagle, 1996), based on the contrast of the very porous, redeposited Tor Formation chalks with the tight basal Ekofisk Formation above, equally shows the top Tor redeposited chalk to be extensive, even indicating filled channels (Mackertich \& Goulding, 1999). Geophysical well log correlation over the Greater Ekofisk area shows that the redeposited chalks immediately below the K-T boundary form a continuous blanket (Kennedy, 1987) that can be $30 \mathrm{~m}$ thick (Fig. 3) and may reach $60 \mathrm{~m}$ (Brasher \& Vagle, 1996). This layer is interpreted by us to represent the single K-T event.

\section{The Silverpit impact}

A recently discovered, circular seismic anomaly in the Silverpit area of the southern North Sea (Fig. 1), has a diameter of approximately $20 \mathrm{~km}$ and is interpreted to have been caused by a small bolide impact (Stew- art \& Allen, 2002). At present, neither the impact origin nor the age of this structure (it can be late Cretaceous to early Tertiary and so brackets the K-T boundary) is beyond doubt. Therefore we do not speculate on its effect in the present context.

\section{Conclusions}

In conclusion, important redeposition of the uppermost Cretaceous chalks in the Greater Ekofisk area of the central North Sea, is interpreted to have been provoked by the K-T boundary Chicxulub bolide impact. Bolide impact was therefore the ultimate cause of the prolific oil reservoirs. Equally, because basin topography immediately following the event became very subdued and no slumping occurred during the early Danian, the impact also had an influence on the formation of a major reservoir seal, the Ekofisk tight zone. Further, the unconformity often indicated at the top of the Maastrichtian, immediately below the $\mathrm{K}-\mathrm{T}$ boundary, was in fact caused by the K-T disturbances and therefore indicates a very short lived event and not either a longer term tectonic uplift and erosion or a sequence stratigraphic type event of lowered sea-level. Our interpretations suggest that large areas of sea floor sedimentation were affected by impact related events at the K-T boundary. In the case of the North Sea chalks it may even suggest new targets for the hydrocarbon industry, perhaps in the well-explored area of the North Sea itself but also along the North Atlantic margins west of Britain and Ireland.

\section{References}

Alvarez, L.W., Alvarez, W., Asaro, F. \& Michel, H.V., 1980. Extraterrestrial cause for the Cretaceous-Tertiary extinction. Science 208: 1095-1108. 
Bralower, T.J., Paull, C.K. \& Leckie, R.M., 1998. The CretaceousTertiary boundary cocktail: Chicxulub impact triggers margin collapse and extensive sediment gravity flows. Geology 26: 331334.

Brasher, J.E. \& Vagle, K.R., 1996. Influence of lithofacies and diagenesis on Norwegian North Sea chalk reservoirs. Bulletin of the American Association of Petroleum Geologists 80: 746-769.

Bramwell, N.P., Caillet, G., Meciani, N., Judge, N.C., Green, M. \& Adam, P., 1999. Chalk exploration, the search for the subtle trap. In: Fleet, A.J. \& Boldy, S.A.R. (Eds): Petroleum Geology of North West Europe. Proceedings of the fifth conference. Geological Society London (London): 911-938.

D'Heur, M., 1986. The Norwegian chalk fields. In: Spencer, A.M. (Ed.): Habitat of hydrocarbons on the Norwegian continental shelf. Graham \& Trotman (London): 77-89.

Farmer, C.L. \& Barkved, O.I., 1999. Influence of syn-depositional faulting on thickness in chalk reservoirs - Valhall and Hod fields. In: Fleet, A.J. \& Boldy, S.A.R. (Eds): Petroleum Geology of North West Europe. Proceedings of the fifth conference. Geological Society (London): 949-957.

Hancock, J.M. \& Scholle, P.A., 1975. Chalk of the North Sea. In: Woodland, A. (Ed.): Petroleum Geology of the Continental Shelf of North-West Europe. Applied Science Publishers (Barking): 413-425.

Johnson, H. \& Lott, G.K.S, 1993. Cretaceous of the Central and Northern North Sea. In: Knox, R.W.O'B \& Cordey, W.G. (Eds): Lithostratigraphic nomenclature of the UK North Sea. British Geological Survey (Nottingham): $169 \mathrm{pp}$.

Kennedy, W.J., 1987. Sedimentology of Late CretaceousPalaeocene chalk reservoirs, North Sea Central Graben. In: Brooks, J. \& Glennie, K.W. (Eds): Petroleum Geology of North West Europe. Proceedings of the third conference. Graham \& Trotman (London): 469-481.

Klaus, A., Norris, R.D., Kroon, D. \& Smit, J., 2000. Impact-induced mass wasting at the K-T boundary: Blake Nose, western North Atlantic. Geology 28: 319-322.

Mackertich, D.S. \& Goulding, D.R.G., 1999. Exploration and appraisal of the South Arne field, Danish North Sea. In: Fleet, A.J. \& Boldy, S.A.R., (Eds): Petroleum Geology of North West Europe. Proceedings of the fifth conference. Geological Society London (London): 959-974.

MacLeod, K.G., Fullagar, P.D. \& Huber, B.T., 2003. ${ }^{87} \mathrm{Sr} /{ }^{86} \mathrm{Sr}$ test of the degree of impact-induced slope failure in the Maastrichtian of the western North Atlantic. Geology 31:311-314

Mukhopadhyay, S., Farley, K.A. \& Montanari, A., 2001. A short duration of the Cretaceous-Tertiary Boundary Event: evidence from extraterrestrial Helium-3. Science 291: 1952-1955.

Norris, R.D., Firth, J., Blusztajn, J.S. \& Ravizza, G., 2000. Mass failure of the North Atlantic margin triggered by the CretaceousPaleogene bolide impact. Geology, 28: 1119-1122.

Norris, R.D. \& Firth, J.V., 2002. Mass wasting of Atlantic continental margins following the Chicxulub impact event. In: Koeberl, C. \& Macleod, K.G. (Eds): Catastrophic events and mass extinctions: impacts and beyond. Geological Society of America, Special Paper 356 (Boulder): 79-95.

Stewart, S.A. \& Allen, P.J., 2002. A 20-km-diameter multi-ringed impact structure in the North Sea. Nature 418: 520-523.

Surlyk, F. A., 1997. Cool-water carbonate ramp with bryozoan mounds: late Cretaceous-Danian of the Danish basin. In: James, N.P. \& Clarke, J.D.A. (Eds): Cool water carbonates. SEPM Special Publication, 56: 293-307.

Ziegler, P.A., 1990. Geological Atlas of Western and Central Europe. Shell International Petroleum Maatschappij B.V., Elsevier Science Publishers (Amsterdam): 130 pp. 